\title{
The effect of Sustainable Frugal Innovations on agriculture productivity
}

\author{
Simbarashe Nhokovedzo ${ }^{1}$, More Chinakidzwa ${ }^{2}$ \\ ${ }^{1}$ Technopreneurship Development Centre, Harare Institute of Technology, Harare , Zimbabwe \\ ${ }^{2}$ Electronic Commerce Department, Harare Institute of Technology, Harare, Zimbabwe \\ E-mail: nhokovedzos@gmail.com; snhokovedzo@hit.zc.zw and $\underline{\text { mchinakidzwa@ hit.ac.zw }}$
}

\begin{abstract}
The dynamism of the agricultural sector environment requires continuous innovation to cope with emerging challenges. Sustainable frugal innovations (SFIs) are an attempt to scale above sustainability challenges in agriculture. Zimbabwe, like many emerging economies has embraced the application of sustainable frugal innovations in farming. The study sought to assess the impact of sustainable frugal innovations on the growth of the agriculture sector. In this study, Agriculture growth is defined as increase in productivity hence the terms growth and productivity are used interchangeably. A quantitative research was adopted to gather data from agriculture experts. Correlation tests were run on economic, environmental and social sustainability against productivity. The relationship between sustainable frugal innovations and agriculture productivity was tested through regression analysis. The findings revealed positive relationship between sustainable frugal innovation and agriculture growth. These findings provide vital insights to motivate creation and adoption of sustainable frugal innovations. Application of sustainable frugal innovations is expected to increase efficiency in production and processing of agriculture produce hence grow the agriculture sector

Keywords: Sustainable frugal innovations, sustainability, frugality, productivity
\end{abstract}

\section{Introduction}

World food demand forecasts predicted that global population needs double the current food production by the year 2050 (Ridley and Hill; 2018, Sayer and Cassman, 2013). Agriculture innovation centres such as scientific laboratories, research institutes, firms and farmers are working on techniques to improve yields, cut costs, enhance nutrition and adapt to climatic change (Ridley and Hill, 2018). From the earliest theories of agriculture productivity, such as the Esther Boserup's agriculture intensification theory, it has been established that increase in agriculture productivity is reliant on innovations. Van der Veen, (2010) posited that agriculture innovation is primarily about increasing production and quality of produce, production process and quality of life. In the progression of green revolution, innovations such as chemical fertilizers, pesticides, herbicides, mechanisation and computerisation has been applied for the intensification of agriculture. Continual agricultural intensification brought new challenges to the farmers and the ecosystems. These challenges included soil salinization, eutrophication, biodiversity loss and toxic accumulation (Ridley and Hill, 2018 and Biswas et al., 2014). Emergent economic, social, sustainability challenges and climate change threats led to new breed of agriculture innovation known as sustainable frugal innovations (Sissoko and Castiaux, 2018). Due to these problems, it has become important for innovators to be mindful of sustainability dimensions when developing agriculture innovations. 
Sustainable frugal innovations are budding innovations which aim to attain sustainability using the minimum possible amounts of resources (Khan, Laurens and Bas, 2019 and Albert, 2019). Like any other agriculture innovations, sustainable frugal innovations are applicable in crop husbandry, animal husbandry, horticulture, agriculture economics and mechanisation (van der Veen, 2010). Whilst researches proved a positive relationship between sustainable agriculture and productivity (Pretty and Thompson, 2002), there are variations as to how economic sustainability, social sustainability and environmental sustainability affect productivity. Lack of clarity on the relationship between sustainable innovations and agriculture growth explains the low adoption of these innovations, as farmers are uncertain about the consequences (Saravanan, 2010). The current study aimed at finding the relationship between sustainable frugal innovations and agriculture productivity.

\section{Literature Review}

\section{Sustainable frugal Innovations}

Sustainable Frugal Innovations (SFIs) is a blend of three words, which are gaining popularity in the $21^{\text {st }}$ century. Khan, Laurens and Bas, (2019), defined Sustainable Frugal innovations as hybrid innovations, which inherit both sustainability and frugality traits. Concurring with Khan, Laurens and Bas, (2019). Albert (2019), described Sustainable frugal innovations as ecological and social sustainable innovations characterised by minimum usage of raw materials, energy, fuel, water, and financial resources. Albert, (2019) added that SFIs are more affordable and better accessible than other conventional innovations available to users. The definitions shows an overlap and a common intersection of sustainability, frugality and innovation. Without necessarily mentioning the term sustainable frugal innovation (Sim, 2014; Khan, 2016; Fredriksson and Tömmervik, 2013; Numminen and Lund, 2017 and Ratten, RamirezPasillas and Lundberg, 2020) confirmed the relationship between sustainability, frugality and innovation despite them referring to different innovation contexts. Illustrating the interconnectedness of sustainability, frugality and innovation (Nhokovedzo, 2021) used the Venn diagram below

\section{Sustainable Frugal Innovations}

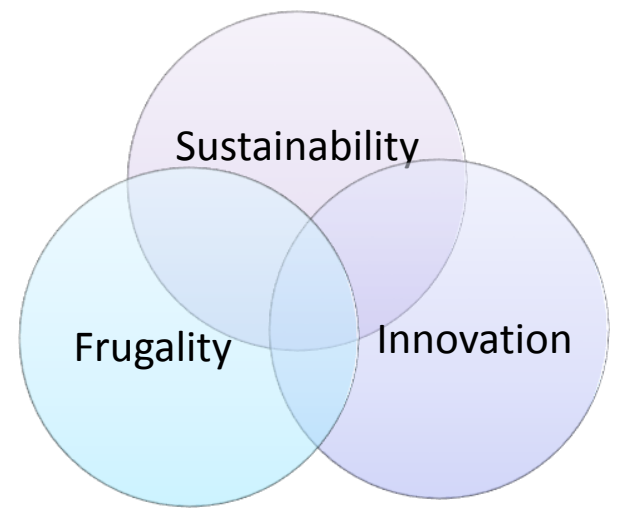

Source (Nhokovedzo, 2021:96)

From reviewing the SFIs concept, Khan, Laurens and Bas, (2019), deduced that frugality contribute to sustainability but not all frugal innovations are sustainable innovations. Similarly, not all sustainable innovations are frugal. The convergence of sustainability and frugality occurs in the context of innovation (Levänen et al., 2016) as both are enhanced by the same. To understand the SFIs concept, it was necessary in this study to disintegrate the phrase back to its founding terms namely sustainability, frugality and innovation as explained in the below table 
Debunking sustainable frugal innovation

\begin{tabular}{|c|c|}
\hline Key term & Definitions \\
\hline Sustainable frugal innovations & $\begin{array}{l}\text { Sustainable Frugal innovations are hybrid innovations, which } \\
\text { inherit both sustainability and frugality traits (Khan, Laurens and } \\
\text { Bas, 2019) Others described Sustainable Frugal Innovations as } \\
\text { ecological and social sustainable innovations characterised by } \\
\text { minimum usage of raw materials, energy, fuel, water, and financial } \\
\text { resources (Khan, Laurens and Bas, 2019, Albert, 2019; Numminen } \\
\text { and Lund, 2017) }\end{array}$ \\
\hline Economic sustainability & $\begin{array}{l}\text { Economic sustainability of an innovation is measured by its ability } \\
\text { to save resources, increase profitability, reduce costs and reduce } \\
\text { wastes (Yurdakul and Kazan, 2020; Birchall et al., 2011; Haskel } \\
\text { and Pesole, } 2009 \text { and Lhuillery, Raffo and Hamdan-Livramento, } \\
\text { 2017) }\end{array}$ \\
\hline Environmental sustainability & $\begin{array}{l}\text { Environmental sustainability of an innovation refers to its ability to } \\
\text { reduce negative ecological effects such as water pollution, } \\
\text { biological hazards, species extinction, air pollution and toxic } \\
\text { accumulation (Pocol et al., 2020;Ratten, Ramirez-Pasillas and } \\
\text { Lundberg, 2020; Grazzi, Sasso and Kemp, 2019) }\end{array}$ \\
\hline Social sustainability & $\begin{array}{l}\text { Social sustainability of an innovation is a quality, which enables } \\
\text { innovations to meet people dimensions such as health, quality of } \\
\text { life, mental wellbeing among others (Maier } \text { et al., } 2020 \text { and Park et } \\
\text { al., 2017) }\end{array}$ \\
\hline Frugal innovations & $\begin{array}{l}\text { Bencsik, Renáta and Tóth, (2016) defined frugal innovation as a } \\
\text { cost effective management philosophy, sustainable development } \\
\text { and reduction of the negative effects of globalisation. Radjou and } \\
\text { Prabhu, (2013) viewed frugal innovation as the ability to do more } \\
\text { with less by creating more business and social value while } \\
\text { minimizing the use of resources such as energy, capital and time. } \\
\text { The constructs of frugal innovations are functionality, affordability, } \\
\text { usability, accessibility, performance, aesthetics, robustnes, } \\
\text { adaptability and modularity (Radjou and Prabhu, 2013) }\end{array}$ \\
\hline Functionability & $\begin{array}{l}\text { Functionality is a quality of value analysis of an innovation. It is a } \\
\text { technical description of an innovation doing what it is made to do } \\
\text { (Aurisicchio et al., 2011) }\end{array}$ \\
\hline Affordability & $\begin{array}{l}\text { Affordability is the quality of an innovation, product or service that } \\
\text { enable purchases by low-income consumers through innovative } \\
\text { designs, pricing, consumer financing and flexible payments } \\
\text { (Tinsley and Agapitova, 2017; Langer, Sood and Yadav, 2014) }\end{array}$ \\
\hline Usability & $\begin{array}{l}\text { Usability is an attribute of simplicity in operation or application of } \\
\text { an innovation in its use.According to Ceccacci, Giraldi and } \\
\text { Mengoni,(2016) usability is the extent to which an innovation can } \\
\text { be used by specified users to attain specified goals with } \\
\text { effectiveness, efficiency and satisfaction contextual to its use. }\end{array}$ \\
\hline Accessibility & $\begin{array}{l}\text { Accessibility is the quality of sustainable frugal innovations to be } \\
\text { available in the potential users' reach. It is the ability to be accessed } \\
\text { in manufacturing, acquisition and utilisation (Sissoko and Castiaux, } \\
\text { 2018; Maat and Konings, 2018) }\end{array}$ \\
\hline
\end{tabular}




\begin{tabular}{|c|c|}
\hline Performance & $\begin{array}{l}\text { Performance is the ability of an innovation to consistently function } \\
\text { the way it is expected to (Brem et al., 2020; Storey and } \\
\text { Easingwood, 1999; Molina-Castillo, Munuera-Alemán and } \\
\text { Calantone, 2011) }\end{array}$ \\
\hline Aesthetics & $\begin{array}{l}\text { Aesthetics refers to the response to an innovation, product, design, } \\
\text { artefact or system, which manifest in senses. The senses such as } \\
\text { vision, hearing, touch smell, taste contribute to aesthetics of a } \\
\text { sustainable frugal innovation (Aurisicchio et al., 2011) }\end{array}$ \\
\hline Robustness & $\begin{array}{l}\text { Robustness is an indicant of consistency in different conditions. A } \\
\text { product or innovation robustness indicates variation in performance } \\
\text { over time despite internal and external variations (Boorla et al., } \\
2018) \text {. According to Boorla et al., (2018) innovation robustness is } \\
\text { the responsibility of engineering design. Parnianifard et al., (2017) } \\
\text { viewed robustness as the designing of a product least sensitive to } \\
\text { the variations in the operating environment to increase reliability } \\
\text { and decrease operating costs. }\end{array}$ \\
\hline Adaptability & $\begin{array}{l}\text { Adaptability is a quality of innovation modifiability to meet the } \\
\text { emerging needs. According to Martinez and Xue (2016) adaptable } \\
\text { product design aim to create innovations that can be easily changed } \\
\text { to satisfy new requirements. Adaptable innovation designs } \\
\text { considers functionality, manufacturing costs, customisation and } \\
\text { environmental sensitivities }\end{array}$ \\
\hline Modularity & $\begin{array}{l}\text { Modularity is a quality of an innovation or product to have } \\
\text { composed elements or modules that can perform independently or } \\
\text { perform distinct functions. The modular design enables autonomy } \\
\text { of parts or components (Pandremenos and Chryssolouris, 2014). } \\
\text { According to Miguel (2005), modularity is a set of principles for } \\
\text { managing complexity in innovation design, it has become } \\
\text { increasingly necessary due to the growing complexity in the } \\
\text { technology world. }\end{array}$ \\
\hline
\end{tabular}

\section{Sustainable frugal innovations in Agriculture}

Under different names, sustainable frugal innovations have been applied in agriculture in recent years. The term sustainable frugal innovation is still new (Nhokovedzo, 2021) but some agriculture innovations in use exhibit the features of sustainable frugal innovations. Some of the commonly used names are sustainable agriculture, smart agriculture technologies, alternative agriculture technologies and conservation farming (Krishnan, Banga and Mendez-Parra, 2020). In less economically developed countries agriculture innovation actors are developing alternative technologies since most farmers cannot afford conventional farming technologies (Sissoko and Castiaux, 2018). Despite the documented benefits of sustainable frugal innovations on the agriculture productivity and the environment, resistance to these innovations has been noted particularly in African countries (Prasetyo et al., 2012). Some of the reasons for resistance to adoption are lack of knowledge about how beneficial these innovations are on productivity and the environment (Prasetyo et al., 2012). Xie et al., (2019) agreed that sustainable innovations have unclear impacts on agriculture hence recommended further studies on their impact on agriculture. In Zimbabwe, there has been considerable attempts to adopt sustainable agriculture innovations that qualify as sustainable frugal innovations. Resistance to these innovations is notable as benefits remains unclear to farmers (Robertson and Harwood, 2013 and Serebrennikov et al., 2020). In neighbouring South Africa, a study by Ntshangase, Muroyiwa and Sibanda, (2018) confirmed resistance to sustainable agriculture innovations, attributing it to farmers negative perceptions. It is against this 
background that this study was conducted to find the relationship between sustainable frugal innovations and agriculture growth

\section{Methods and Instruments}

The study adopted a quantitative methodology in determining the perceived effect of sustainable frugal innovations on agriculture growth. A sample of 218 respondents was drawn from various subsectors of the Zimbabwean agriculture sector such as agronomy, mechanisation, animal husbandry and agriculture economics. The study applied a stratified random sampling method (Kumar, 2012), stratifying according to areas of specialisation.. A randomised sampling criterion was applied with each stratum and a standard questionnaire was administered to the informants through electronic means. A one directional correlational analysis was performed on the sustainable frugal innovations variables against agriculture productivity. A regression analysis of sustainable frugal innovation and agriculture productivity was performed.

\section{Instrument development and data collection procedures}

A standardised questionnaire was chosen as the optimum measurement continuum (Boateng, Neilands and Frongillo, 2018). The instrument was configured into an online form, google survey format for easy distribution and convenience in responding using electronic gadgets such as computers and smart phones. The methods of data collection applied were fully compliant with the Covid 19 protocols. Telephonic calls and social media messages were used for seeking consent, reminding the respondents and thanking them.

\section{Quality control protocols}

A miniature data collection was done to test the flow of the study instrument. Reliability of the instrument was tested using SPSS interpreted using the Cronbach's alpha. The sample adequacy was tested using $\mathrm{KMO}$ and Bartlett test. A response rate of $78 \%$ was recorded and considered sufficient (Fincham, 2008).

\section{Relationship between Sustainable Frugal Innovations and agriculture sector growth Economic sustainability and agriculture growth}

The research endeavoured to establish the relationship between economic sustainability and agriculture growth. The term growth in these tests refers to agriculture productivity. First, a transformed variable of economic sustainability was computed using SPSS. A one tail Spearman's correlation test was performed giving the test scores below.

\section{Correlations}

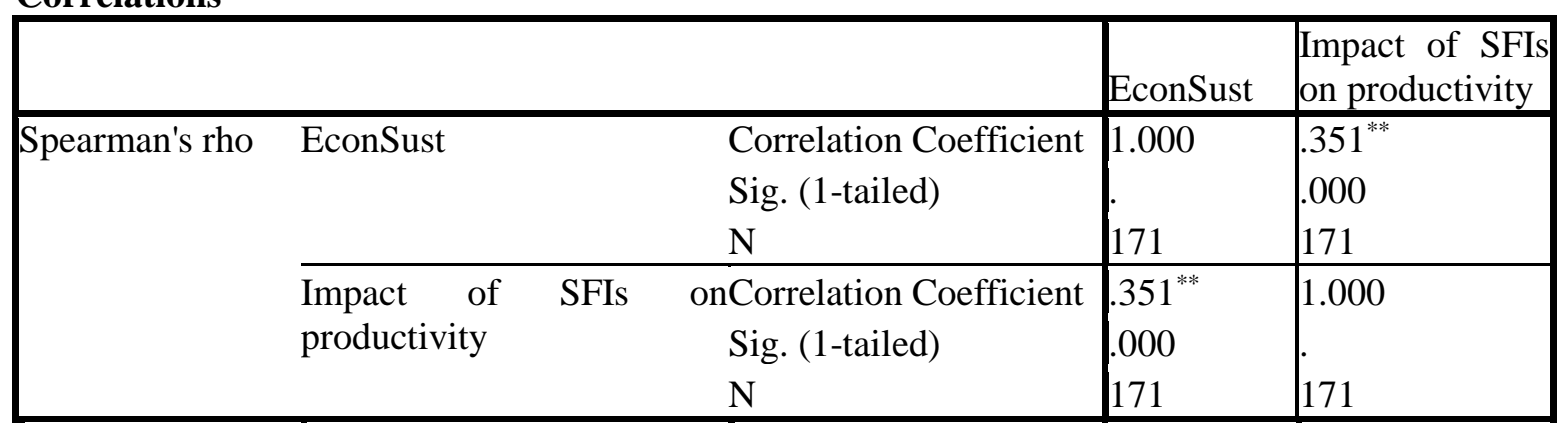

**. Correlation is significant at the 0.05 level (1-tailed).

Economic sustainability and agriculture productivity are positively correlated at a magnitude of 0.351 . The strength of the positive relationship is moderate since it falls in the 0,3-0,5 band (Kumar, 2012 and Kothari, 2004) 
Volume 3, Issue 2, 2021

ISSN: 2668-0416

Thoth Publishing House

Environmental sustainability and agriculture growth

Environmental sustainability was correlated with agriculture growth to determine the significance, direction and magnitude of relationship. The one tail Spearman correlation test produced the tabulated results

Correlations

\begin{tabular}{|c|c|c|c|c|}
\hline & & & EnvSus & $\begin{array}{l}\text { Impact of SFIs } \\
\text { on productivity }\end{array}$ \\
\hline \multirow[t]{2}{*}{ Spearman's rho } & EnvSus & $\begin{array}{l}\text { Correlation Coefficient } \\
\text { Sig. (1-tailed) } \\
\text { N }\end{array}$ & $\begin{array}{l}1.000 \\
171\end{array}$ & $\begin{array}{l}.149^{*} \\
.026 \\
171\end{array}$ \\
\hline & $\begin{array}{l}\text { Impact of } \\
\text { productivity }\end{array}$ & $\begin{array}{l}\text { onCorrelation Coefficient } \\
\text { Sig. (1-tailed) } \\
\text { N }\end{array}$ & $\begin{array}{l}149^{*} \\
026 \\
171\end{array}$ & $\begin{array}{l}1.000 \\
171\end{array}$ \\
\hline
\end{tabular}

*. Correlation is significant at the 0.05 level (1-tailed).

At a 95\% confidence level, the test produced a weak positive relationship of 0.149 percent. The test was significant, with a p value of 0.026 .

\section{Social sustainability and agriculture growth}

A transformed social sustainability variable, which consist of all the extracted constructs, was built in SPSS and correlated with productivity using the Spearman's correlation tests. The test results were as below

Correlations

\begin{tabular}{|c|c|c|c|c|}
\hline & & & SocSust & $\begin{array}{l}\text { Impact of SFIs } \\
\text { on productivity }\end{array}$ \\
\hline \multirow[t]{2}{*}{ Spearman's rho } & SocSust & $\begin{array}{l}\text { Correlation Coefficient } \\
\text { Sig. (1-tailed) }\end{array}$ & 1.000 & $\begin{array}{l}356^{* *} \\
.000\end{array}$ \\
\hline & $\begin{array}{l}\text { Impact of SFIs } \\
\text { productivity }\end{array}$ & $\begin{array}{l}\text { onCorrelation Coefficient } \\
\text { Sig. (1-tailed) }\end{array}$ & $\begin{array}{l}.356^{* *} \\
.000\end{array}$ & 1.000 \\
\hline
\end{tabular}

**. Correlation is significant at the 0.05 level (1-tailed).

b. Listwise $\mathrm{N}=171$

At a stricter confidence interval of $95 \%$, it was established that there is a moderately strong, positive relationship between social sustainability and agriculture productivity. The test was significant with pvalue of .000 , which is less than 0.05 .

\section{Frugality and agriculture growth}

The frugality variable, comprised of its constructs namely, functionality, usability, adaptability, aesthetics, accessibility, robustness and modularity, was correlated with agriculture growth using the Spearman's test. Test scores were as below

\section{Correlations}

\begin{tabular}{|c|c|c|c|c|}
\hline & & & $\begin{array}{l}\text { Impact of SFI } \\
\text { on productivity }\end{array}$ & Fruga \\
\hline \multirow[t]{2}{*}{ Spearman's rho } & $\begin{array}{l}\text { Impact of } \\
\text { productivity }\end{array}$ & $\begin{array}{l}\text { onCorrelation Coefficient } \\
\text { Sig. (1-tailed) } \\
\text { N }\end{array}$ & $\begin{array}{l}1.000 \\
171\end{array}$ & $\begin{array}{l}715^{* *} \\
.000 \\
171\end{array}$ \\
\hline & Fruga & $\begin{array}{l}\text { Correlation Coefficient } \\
\text { Sig. (1-tailed) } \\
\mathrm{N}\end{array}$ & $\begin{array}{l}.715^{* *} \\
.000 \\
171\end{array}$ & $\begin{array}{l}1.000 \\
171\end{array}$ \\
\hline
\end{tabular}

**. Correlation is significant at the 0.05 level (1-tailed). 
At $95 \%$ confidence interval, a very strong magnitude of 0.715 was established in a positive direction. Frugality greatly contribute to the growth of the agriculture sector. The test significance was 0.000 , which is within the acceptable threshold of less than 0.05 .

\section{Impact of Sustainable Frugal innovations on agriculture growth}

The research sought to determine the relationship between sustainable frugal innovations and the growth of the agriculture sector. This was the mainstay of the current study. A one tail, Spearman test was performed and the test scores were as below

\section{Correlations}

\begin{tabular}{|c|c|c|c|c|}
\hline & & & SFI & $\begin{array}{l}\text { Impact of SFIs } \\
\text { on productivity }\end{array}$ \\
\hline \multirow[t]{2}{*}{ Spearman's rho } & SFI & $\begin{array}{l}\text { Correlation Coefficient } \\
\text { Sig. (1-tailed) } \\
\mathrm{N}\end{array}$ & {$\left[\begin{array}{l}1.000 \\
171\end{array}\right.$} & $\begin{array}{l}.525^{* *} \\
.000 \\
171\end{array}$ \\
\hline & $\begin{array}{l}\text { Impact of } \\
\text { productivity }\end{array}$ & $\begin{array}{l}\text { onCorrelation Coefficient } \\
\text { Sig. (1-tailed) } \\
\text { N }\end{array}$ & $\begin{array}{l}.525^{* *} \\
.000 \\
171\end{array}$ & $\begin{array}{l}1.000 \\
171\end{array}$ \\
\hline
\end{tabular}

**. Correlation is significant at the 0.05 level (1-tailed).

A strong positive relationship between sustainable frugal innovations and agriculture growth was established. The test was significant, with a p-value of .000 .

\section{Regression analysis}

There was need to perform a regression analysis to precisely estimate the influence of Sustainable Frugal Innovations (SFIs) on agriculture growth. The regression outcome is tabulated below

\section{Model Summary}

\begin{tabular}{|l|l|l|l|l|}
\hline Model & $\mathrm{R}$ & R Square & $\begin{array}{l}\text { Adjusted } \\
\text { Square }\end{array}$ & $\begin{array}{l}\text { R } \\
\text { Std. Error of the } \\
\text { Estimate }\end{array}$ \\
\hline 1 & $.556^{\mathrm{a}}$ & .309 & .305 & .587 \\
\hline
\end{tabular}

a. Predictors: (Constant), SFI

b. Dependent Variable: Agriculture productivity

A regression analysis was done between sustainable frugal innovations and the agriculture productivity. The findings in the table of the model summary give R Square value of .309 and Adjusted R Square is .305. The researcher used the Adjusted R. Square (Kothari, 2004; Bhattacherjee, 2012 and Kumar, 2012) because it is more accurate in sharing the predictive power on the dependent variable. As a percentage, productivity is explained $30.7 \%$ by sustainable frugal innovations. However, the remaining $69.3 \%$ is explained by other variables, other than sustainable frugal innovations. These other factors could be farmers' incentives, climatic variables, edaphic variables and pestilence infestations.

ANOVA $^{\mathrm{a}}$

\begin{tabular}{|ll|l|l|l|l|l|}
\hline Model & & Sum of Squares & Df & Mean Square & F & Sig. \\
\hline 1 & Regression & 26.029 & 1 & 26.029 & 75.590 & $.000^{\mathrm{b}}$ \\
Residual & 58.193 & 169 & .344 & & \\
Total & 84.222 & 170 & & & \\
\hline
\end{tabular}

a. Dependent Variable: Agriculture productivity

b. Predictors: (Constant), SFI 
An ANOVA analysis was performed between environmental sustainability and agriculture productivity at $95 \%$ confidence interval. The F value of 75.590 was obtained and a P-Value of 0.000 . Since the Pvalue of 0.000 is less than 0.05 . Therefore, it is established that there is a linear positive relationship between sustainable frugal innovations and increase in agriculture productivity.

\section{Discussion}

The research tested a one directional relationship between Sustainable Frugal Innovations and growth of the agriculture sector. A positive relationship was determined through a correlational and regression analysis. The findings shows that application of sustainable frugal innovations improve economic, environmental and social sustainability although at varying magnitudes. Economic sustainability of agriculture innovations contribute more to agriculture productivity than the environmental and social sustainability of the same innovations. Tomchek, (2021) findings on the impact of sustainable innovations on agriculture resonates with the findings of the current study. Congruent to the positions shared earlier mentioned, (Tomchek, 2021) advised that developing countries seek affordable technologies which are easy to access. Such technologies are the sustainable frugal innovations. A somewhat weak correlation was established between environmental sustainability of agriculture innovations and agriculture productivity. Most fertilizer formulations and agrochemicals used in agriculture intensification are largely detrimental to the environmental health (Biswas et al., 2014). The weak relationship between environmental sustainability and productivity is in partial convergence with (Prada, Bravo-ureta and Shah, 2003) findings which concluded a negative relationship between the two.

Previous studies are generally concurring with the positive impact of sustainable agriculture innovations on growth (Ridley and Hill, 2018 and van der Veen, 2010). Ogundari and Bolarinwa, (2018) carried out a meta-analysis, reviewing over 150 journals; the conclusion was a positive relationship between innovations an economic, environmental and social aspects of agriculture. There is a striking resonance between the current study and Ogundari and Bolarinwa, (2018) research because the later was biased towards contemporary innovation forms and technologies of which Sustainable Frugal Innovations are part of. In the same vein, researches on frugality effects are in harmony with current research findings. The essence of frugality is to achieve, more with less for more, (Khan, 2016 and Khan, Laurens and Bas, 2019). However, some findings diverge from the current study findings as they establish a negative relationship between sustainable agriculture and productivity (Prada, Bravo-ureta and Shah, 2003). The debate is heavily titled against aspects of environmental sustainability (Prada, Bravo-ureta and Shah, 2003). Overall, the current and previous research findings are in synch on the positivity of the relationship between Sustainable Frugal Innovations and growth.

\section{Conclusion}

The study concluded that sustainable frugal innovations positively contribute to agriculture growth. Therefore, sustainable frugal innovations have a huge potential to alter the agriculture growth trajectory of developing countries. In a world where sustainability in agriculture is now topical, sustainable frugal innovations are a possible option towards achievement it. The race to sustainable agriculture is in line with the United Nations Sustainable Development goal number 2. The creation, adoption and utilisation of sustainable frugal innovations is important in achieving the SDG 2. Lastly, burdens of poor farmers who use labour intensive and ineffective traditional farming methods could be lessened through application of these affordable innovations.

\section{References}

[1] Albert, M. (2019) 'Sustainable frugal innovation - The connection between frugal innovation and sustainability’, Journal of Cleaner Production, 237, p. 117747. doi: 10.1016/j.jclepro.2019.117747.

[2] Aurisicchio, M. et al. (2011) 'On the functions of products', ICED 11 - 18th International Conference on Engineering Design - Impacting Society Through Engineering Design, 10(PART 2), pp. 443-455. 
[3] Bencsik, A., Renáta, M. and Tóth, Z. (2016) 'Cheap and clever - symbiosis of frugal innovation and knowledge management', Problems and Perspectives in Management, 14(1), pp. 85-93. doi: 10.21511/ppm.14(1).2016.10.

[4] Bhattacherjee, A. (2012) Social Science Research: Principles, Methods, and Practices.

[5] Birchall, D. et al. (2011) 'Innovation performance measurement: Current practices, issues and management challenges', International Journal of Technology Management, 56(1), pp. 1-20. doi: 10.1504/IJTM.2011.042492.

[6] Biswas, S. K. et al. (2014) 'A Review on Impact of Agrochemicals on Human Health and Environment : Bangladesh Perspective A Review on Impact of Agrochemicals on Human Health and Environment: Bangladesh Perspective', Plant Environment Development, 3(2), pp. 31-35.

[7] Boateng, G. O., Neilands, T. B. and Frongillo, E. A. (2018) 'Best Practices for Developing and Validating Scales for Health, Social, and Behavioral Research: A Primer', (June). doi: 10.3389/fpubh.2018.00149.

[8] Boorla, M. S. et al. (2018) 'Product robustness philosophy - A strategy towards zero variation manufacturing (ZVM)', Management and Production Engineering Review, 9(2), pp. 3-12. doi: $10.24425 / 119520$.

[9] Brem, A. et al. (2020) 'How to design and construct an innovative frugal product? An empirical examination of a frugal new product development process', Journal of Cleaner Production, 275, p. 122232. doi: 10.1016/j.jclepro.2020.122232.

[10] Ceccacci, S., Giraldi, L. and Mengoni, M. (2016) 'Product usability: Is it a criterion to measure "Good UX" or a prerequisite?', Proceedings of the ASME Design Engineering Technical Conference, 1A-2016(August). doi: 10.1115/DETC2016-59500.

[11] Fincham, J. E. (2008) 'Response rates and responsiveness for surveys, standards, and the Journal.', American journal of pharmaceutical education, 72(2), p. 43. doi: 10.5688/aj720243.

[12] Fredriksson, E. and Tömmervik, J. (2013) 'Frugal is the new innovative thinking: A qualitative study of frugal innovations and sustainable development in resource-poor environments'.

[13] Grazzi, M., Sasso, S. and Kemp, R. (2019) 'A Conceptual Framework to Measure Green Innovation in Latin America and the Caribbean', Mdpi.Com. Available at: https://www.researchgate.net/publication/340535985.

[14] Haskel, J. and Pesole, A. (2009) 'Productivity and Innovation in UK Financial Services: An Intangible Assets Approach', Business, (217512), pp. 0-33.

[15] Khan, R. (2016) 'How frugal innovation promotes social sustainability', Sustainability (Switzerland), 8(10). doi: 10.3390/su8101034.

[16] Khan, S., Laurens, P. and Bas, C. Le (2019) 'Frugal Innovation, Sustainability, and Sustainable Frugal Innovation: A conceptual clarification and empirical evidence', AIMs conference Dakar June, pp. 1-19.

[17] Kothari, C. R. (2004) Research Methodology.

[18] Krishnan, A., Banga, K. and Mendez-Parra, M. (2020) 'Disruptive technologies in agricultural value chains Insights from East Africa', (1), pp. 1-60.

[19] Kuhlman, T. and Farrington, J. (2010) 'What is sustainability?', Sustainability, 2(11), pp. 34363448. doi: $10.3390 / \mathrm{su} 2113436$.

[20] Kumar, R. (2012) Research Methodology, הנוטע עלון.

[21] Langer, T.-A., Sood, A. and Yadav, L. (2014) 'Goodness through Jugaad ( Frugal Innovation ) Disruptive Innovation in Agriculture Sector in India'.

[22] Levänen, J. et al. (2016) 'Implications of frugal innovations on sustainable development: Evaluating water and energy innovations', Sustainability (Switzerland), 8(1), pp. 1-17. doi: $10.3390 /$ su8010004.

[23] Lhuillery, S., Raffo, J. and Hamdan-Livramento, I. (2017) 'Measurement of innovation', The Elgar Companion to Innovation and Knowledge Creation, (November), pp. 99-118. doi: $10.4337 / 9781782548522.00013$.

[24] Maat, K. and Konings, R. (2018) 'Accessibility or Innovation? Store Shopping Trips versus Online 
Shopping'. doi: 10.1177/0361198118794044.

[25] Maier, D. et al. (2020) 'The relationship between innovation and sustainability: A bibliometric review of the literature', Sustainability (Switzerland), 12(10). doi: 10.3390/SU12104083.

[26] Martinez, M. and Xue, D. (2016) 'Development of Adaptable Products Based on Modular Design and Optimization Methods', Procedia CIRP, 50, pp. 70-75. doi: 10.1016/j.procir.2016.04.078.

[27] Mazvimavi, K. et al. (2010) 'Conservation Agriculture Practices and Adoption by Smallholder Farmers in Zimbabwe', Proceedings from the Joint 3rd African Association of Agricultural Economists and 48th Agricultural Economists of South Africa, p. 20.

[28] Miguel, P. (2005) 'Modularity in product development: a literature review towards a research agenda', Product: Management \& Development, 3(2), pp. 165-174.

[29] Molina-Castillo, F. J., Munuera-Alemán, J. L. and Calantone, R. J. (2011) 'Product quality and new product performance: The role of network externalities and switching costs', Journal of Product Innovation Management, 28(6), pp. 915-929. doi: 10.1111/j.1540-5885.2011.00847.x.

[30] Muzari, W. et al. (2013) 'The impacts of agricultural technology use on productivity and food security among smallholder farmers in Zimbabwe: The case of Makonde district', Journal of Agricultural Extension and Rural Development, 5(10), pp. 225-231. doi: 10.5897/JAERD2013.0503.

[31] Nhokovedzo, S. (2021) 'Construction of Sustainable Frugal Innovations Index for the Agriculture Sector', International Journal of Sustainable Agricultural Research, 8(2), pp. 93-104. doi: 10.18488/journal.70.2021.82.93.104.

[32] Ntshangase, N. L., Muroyiwa, B. and Sibanda, M. (2018) 'Farmers' perceptions and factors influencing the adoption of no-till conservation agriculture by small-scale farmers in Zashuke, KwaZulu-Natal province', Sustainability (Switzerland), 10(2). doi: 10.3390/su10020555.

[33] Numminen, S. and Lund, P. D. (2017) 'Frugal energy innovations for developing countries - a framework', Global Challenges, 1(1), pp. 9-19. doi: 10.1002/gch2.1012.

[34] Ogundari, K. and Bolarinwa, O. D. (2018) 'Impact of agricultural innovation adoption: a metaanalysis', Australian Journal of Agricultural and Resource Economics, 62(2), pp. 217-236. doi: 10.1111/1467-8489.12247.

[35] Pandremenos, J. and Chryssolouris, G. (2014) 'Modular product design and customization', Competitive Design - Proceedings of the 19th CIRP Design Conference, (January 2014), pp. 94 98.

[36] Park, M. S. et al. (2017) 'Eco-innovation indices as tools for measuring eco-innovation', Sustainability (Switzerland), 9(12). doi: 10.3390/su9122206.

[37] Parnianifard, A. et al. (2017) 'Robust Product Design : A Modern View of Quality Engineering in Manufacturing Systems', International Journal of Recent Advances in Multidisciplinary Research, 4(12), pp. 3220-3225. doi: 10.20944/PREPRINTS201807.0517.V1.

[38] Philip Robertson, G. and Harwood, R. R. (2013) 'Agriculture, Sustainable', Encyclopedia of Biodiversity: Second Edition, 1, pp. 111-118. doi: 10.1016/B978-0-12-384719-5.00287-2.

[39] Pocol, C. B. et al. (2020) 'Sustainable vs. unsustainable food consumption behaviour: A study among students from Romania, Bulgaria, and Moldova', Sustainability (Switzerland), 12(11). doi: $10.3390 /$ su12114699.

[40] Prada, J. D. De, Bravo-ureta, B. and Shah, F. (2003) 'Agricultural Productivity and Sustainability : Evidence from Low Input Farming in Argentina', Office, pp. 1-26.

[41] Prasetyo, Y. E. et al. (2012) 'Resistance to Innovation: Case of Appropriate Technology Implementation in Rural Agriculture Communities', SSRN Electronic Journal, (January 2018). doi: $10.2139 /$ ssrn.2101656.

[42] Pretty Jules, John Thompson, F. H. (2002) 'Sustainable Agriculture : Impacts on Food Production and Challenges for Food Security', International Institute for Environment and Development Gatekeeper Series, (60), pp. 1-25. 
[43] Radjou, N. and Prabhu, J. (2013) 'Frugal Innovation: A New Business Paradigm.', INSEAD Knowledge Publications, pp. 1-3. Available at: http://search.ebscohost.com/login.aspx?direct=true \&db=bth\&AN=86040316\&site=ehost-live.

[44] Ratten, V., Ramirez-Pasillas, M. and Lundberg, H. (2020) Managing sustainable innovation, Managing Sustainable Innovation. doi: 10.4324/9780429264962-1.

[45] Ridley, M. and Hill, D. (2018) 'The effect of innovation in agriculture on the enviroment', (64), pp. 1-108.

[46] Saravanan, R. (2010) 'Agricultural Knowledge Information Systems and Innovations for Technology Dissemination and Sustainable Agricultural Development', Innovation and Suistanable Development, (June 2010), pp. 1-8.

[47] Sayer, J. and Cassman, K. G. (2013) 'Agricultural innovation to protect the environment', Proceedings of the National Academy of Sciences of the United States of America, 110(21), pp. 8345-8348. doi: 10.1073/pnas.1208054110.

[48] Serebrennikov, D. et al. (2020) 'Factors influencing adoption of sustainable farming practices in europe: A systemic review of empirical literature', Sustainability (Switzerland), 12(22), pp. 1-23. doi: 10.3390/su12229719.

[49] Sim, L. (2014) 'Assessing the Social Sustainability of Frugal Products'.

[50] Sissoko, M. and Castiaux, A. (2018) 'How does frugal innovation emerge and lead to sustainability in developing countries? A case study in Malian agricultural areas . How does frugal innovation emerge and lead to sustainability in developing countries? A case study in Malian agricultural a', 166th EAAE seminar Sustainability in the Agri-Food Sector, pp. 1-22.

[51] Storey, C. and Easingwood, C. J. (1999) 'Types of New Product Performance', Journal of Business Research, 46(2), pp. 193-203. doi: 10.1016/s0148-2963(98)00022-8.

[52] Tinsley, E. and Agapitova, N. (2017) 'Making Products and Services Affordable for Low- Income Consumers', pp. 1-9.

[53] Tomchek, M. (2021) 'Sustainable Technology Impact on Agricultural Production', (January), pp. 1024-1037. doi: 10.1007/978-3-319-95867-5_128.

[54] van der Veen, M. (2010) 'Agricultural innovation: Invention and adoption or change and adaptation?', World Archaeology, 42(1), pp. 1-12. doi: 10.1080/00438240903429649.

[55] Xie, H. et al. (2019) 'Prospects for agricultural sustainable intensification: A review of research', Land, 8(11), pp. 1-27. doi: 10.3390/land8110157.

[56] Yurdakul, M. and Kazan, H. (2020) 'Effects of eco-innovation on economic and environmental performance: Evidence from Turkey's manufacturing companies', Sustainability (Switzerland), 12(8), p. 3167. doi: 10.3390/SU12083167. 